\title{
FAKTOR-FAKTOR YANG BERHUBUNGAN DENGAN GANGGUAN PENDENGARAN PADA TENAGA KERJA PT BNT BENGKULU TENGAH
}

\author{
Sri Mulyati, Jubaidi, Haidina Ali \\ Politeknik Kesehatan Kementerian Kesehatan Bengkulu, Jurusan Kesehatan Lingkungan, \\ Jalan Indragiri Nomor 03 Padang Harapan Kota Bengkulu \\ srimulyati_2202@yahoo.co.id
}

\begin{abstract}
Continuous and uncertainty noise exposure have possibility in disruption of hearing. These disorders can be both temporary and permanent, besides the noise also can lead to a sense of uncomfortable, anxiety, stress, the increased of heart rate, as well as other disorders of Occupational Accidents (KAK), Occupational Diseases and Diseases of Employment increased in the last three years since the year 2012 until 2014 amounted to 5\%, 7\% and 10\%. This study aimed to know the factors associated with hearing loss in labor of PT BNT. This research used observational with cross sectional approach. The sample in this research amounted to 56 people with purposive sampling technique. Data were analised using univariat, bivariat Chi Square and simple multivariate regress logistic regression. There was a significant relationship among the use of PPE of employment, labor knowledge of employment, age of employment, the period of employment, the level of noise with hearing loss of labor of PT BNT. The most dominant factor affecting hearing loss occurs was work period with Exp (B) 23.889. The use of Personal Protection Tool for workers, especially Ears Protection in every working chance in the process of continuous employment, increase the habit of using whether with or without supervision, maintain Personal Protection Tool individually and continuously and for PT BNT In the process of personal protective equipment should be fully prepared, especially Ear Protection Tool Equipment,check the health workforce in the process periodically and regularly, especially the auditory system, Enforce reward for workers who use Personal Protection Tool continuously and punishment for workers who often do not use Personal Protection Tool.
\end{abstract}

Keyword: The use of PPE, Knowledge, Age, Work Period, Noise, Hearing loss

\begin{abstract}
Abstrak: Gangguan pendengaran akibat paparan kebisingan dapat merusak alat pendenganran yang bersifat sementara maupun permanen. Hal ini mengakibatkan rasa tidak nyaman, kecemasan, stres, denyut jantung bertambah, serta gangguan lainnya Kecelakaan Akibat Kerja (KAK), Penyakit Akibat Kerja (PAK) dan Penyakit Akibat Hubungan Kerja (PAHK) yang meningkat dalam tiga tahun terakhir sejak tahun 2012 sd 2014 sebanyak $5 \%, 7 \%$ dan $10 \%$. Tujuan penelitian ini untuk mengetahui faktor-faktor yang berhubungan dengan gangguan pendengaran pada tenaga kerja PT BNT. Penelitian ini merupakan penelitian observasional dengan pendekatan cross sectional. Sampel dalam penelitian ini berjumlah 56 orang yang diambil secara purposive sampling. Analisis data dilakukan univariat, bivariat dengan uji Chi Square dan multivariate dengan uji regresi logistik sederhana. Hasil analisis menunjukkan ada hubungan yang signifikan antara penggunaan Alat Pelindung Diri (APD), pengetahuan, umur, masa kerja, tingkat kebisingan dengan gangguan pendengaran tenaga kerja di PT BNT. Faktor yang paling dominan mempengaruhi terjadinya gangguan pendengaran adalah masa kerja dengan nilai $\operatorname{Exp}(\mathrm{B}) 23,889$. Diharapkan tenaga kerja menggunakan APD terutama Alat Pelindung Telinga (APT) setiap berada di lingkungan pekerjaan dibagian proses secara kontinyu, tingkatkan kebiasaan menggunakan APD pada saat ada atau tidak ada pengawasan, pelihara APD secara perseorangan dan kontinyu dan untuk PT BNT pada bagian proses sebaiknya APD disiapkan secara lengkap, terutama APT, periksalah kesehatan tenaga kerja pada bagian proses secara periodik dan teratur, berlakukan penghargaan bagi tenaga kerja yang menggunakan APD secara kontinyu dan hukuman bagi tenaga kerja yang sering kali tidak menggunakan APD.
\end{abstract}

Kata Kunci : Penggunaan APD, Pengetahuan, Umur, Masa Kerja, Kebisingan, Gangguan pendengaran 
Tenaga kerja sebagai sumber daya manusia, perlu mendapat perhatian khusus baik kemampuan, keselamatan, maupun kesehatan kerjanya. Upaya perlindungan tenaga kerja perlu diterapkan karena berhubungan dengan kesehatan tenaga kerja. Resiko bahaya yang dihadapi oleh tenaga kerja adalah bahaya kecelakaan dan penyakit akibat kerja, akibat kombinasi dari berbagai faktor yaitu tenaga kerja dan lingkungan kerja (Suma'mur, 2009). Pemaparan kebisingan yang terus menerus dan berlangsung lama akan mengakibatkan gangguan alat pendengaran.

Gangguan ini dapat bersifat sementara maupun permanen. Selain itu kebisingan juga dapat mengakibatkan rasa tidak nyaman, stres, kecemasan, denyut jantung bertambah, serta gangguan lainnya (Mulyanti, 2009). Menurut Sari (2012) kebisingan dapat berdampak pada indera pendengaran (gangguan komunikasi, gangguan tidur, perasaan mudah marah dan stress). PT Bio Nusantara Teknologi (BNT) terletak di kecamatan Pondok Kelapa, kecamatan Pematang Tiga dan kecamatan Taba Penanjung wilayah kabupaten Bengkulu Tengah, memproduksi minyak olahan dengan bahan baku kelapa sawit. PT BNT memiliki karyawan 802 pekerja dengan Kecelakaan Akibat Kerja (KAK), Penyakit Akibat Kerja (PAK) dan Penyakit Akibat Hubungan Kerja (PAHK) yang meningkat dalam tiga tahun terakhir sejak tahun 2012 sampai 2014 sebanyak 5\%,7\% dan $10 \%$.

Telinga manusia hanya mampu menangkap suara yang ukuran intensitasnya berkisar antara $20-20.000 \mathrm{~Hz}$ dan dengan frekuensi suara sekitar $80 \mathrm{~dB}$. Lebar reservoir telinga manusia diantara $0 \mathrm{~dB}-140 \mathrm{~dB}$ yang dapat didengar. Batas intensitas suara tertinggi adalah $140 \mathrm{~dB}$ dan apabila untuk mendengarkan suara itu sudah timbul perasaan sakit pada alat pendengaran. Pajanan terhadap suara atau bunyi yang melampaui batas aman dalam waktu yang lama dapat menyebabkan terjadinya ketulian sementara atau permanen (Chandra, 2007).

APT adalah alat yang digunakan untuk menyumbat telinga atau menutup telinga yang digunakan atau dipakai dengan tujuan melindungi, mengurangi paparan kebisingan yang masuk ke dalam telinga (Tarwaka,2009). Sumbat telinga (Ear Plug) memberikan perlindungan yang paling efektif karena langsung dimasukkan ke dalam telinga. Ear Plug harus dipilih sesuai dengan ukuran, bentuk, posisi saluran telinga pemakainya. Tutup telinga (ear muff) APT jenis ini terdiri dari dua buah tutup telinga dan sebuah headband.Isi dari tutup telinga dapat berupa cairan atau busa yang berfungsi untuk menyerap suara frekuensi tinggi. Pada pemakaian untuk waktu yang cukup gan lama, efektivitas ear muff dapat menurun karena bantalan mengeras dan mengerut sebagai akibat deretan bantalan dengan minyak dan keringat pada permukaan kulit.

Notoatmodjo (2011), menyatakan bahwa pengetahuan adalah hasil dari tahu, dan ini terjadi setelah orang melakukan penginderaan terhadap suatu obyek tertentu. Umur adalah umur yang dihitung mulai dilahirkan sampai dengan ulang tahun terakhir dan pekerja yang lebih tua dianggap lebih cakap secara teknis. Suatu keyakinan bahwa produktifitas menurun seiring dengan menuanya umur seseorang (Mulyanti, 2009).

Keterampilan seseorang berkaitan dengan kekuatan, koordinasi dan hal lain akan menurun bersama umur yang bertambah (Anonim, 2003). Masa kerja adalah berapa lama seseorang bekerja pada masing-masing pekerjaan atau jabatan. Masa kerja pekerja ada tiga kategori yaitu: masa kerja baru : 5 tahun, dan masa kerja lama : 5 tahun (Siagian, 2008). Tujuan penelitian untuk mengetahui faktor-faktor yang berhubungan dengan gangguan pendengaran pada tenaga kerja PT Bio Nusantara Teknologi Bengkulu Tengah Tahun 2014.

\section{BAHAN DAN CARA KERJA}

Penelitian ini adalah penelitian observasional dengan pendekatan cross sectional. Populasi dalam penelitian ini adalah semua pekerja pada bagian proses berjumlah 78 orang. Sampel dalam penelitian ini berjumlah 56 orang. 22 orang 
tidak hadir dalam pengumpulan data (ijin, tidak mau dilakukan pemeriksaan). Teknik pengambilan sampel secara purposive sampling. Analisis data dilakukan secara univariat dengan persentase, bivariat dengan Chi Square dan multivariat dengan regresi logistik sederhana

\section{HASIL}

\section{Analisis Univariat}

Berdasarkan tabel 1 diketahui bahwa dari 56 responden didapatkan lebih dari setengah (57\%) kurang dalam penggunaan APD, lebih dari setengah (64\%) dengan pengetahuan tenaga kerja dalam kategori kurang, sebagian besar (71\%) dengan umur dalam kategori muda, lebih dari setengah (54\%) dengan masa kerja lama, lebih dari setengah $(61 \%)$ dengan tingkat kebisingan tinggi dan lebih dari setengah (52\%) dengan tenaga kerja mengalami gangguan pendengaran.

Tabel 1. Gambaran Penggunaan APD, Pengetahuan, Umur, Masa Kerja, Tingkat Kebisingan Dan Gangguan Pendengaran

\begin{tabular}{lll}
\hline \multicolumn{1}{c}{ variabel } & $\begin{array}{c}\text { Frekuensi } \\
(\mathbf{n = 5 6})\end{array}$ & $\begin{array}{c}\text { Presentase } \\
(\mathbf{1 0 0 \% )})\end{array}$ \\
\hline $\begin{array}{l}\text { Penggunaan APD } \\
\text { Kurang }\end{array}$ & 32 & 57 \\
Baik & 24 & 43 \\
$\begin{array}{l}\text { Pengetahuan } \\
\text { Kurang }\end{array}$ & & \\
Cukup & 36 & 64 \\
Umur & 20 & 36 \\
Tua & & \\
Muda & 16 & 29 \\
Masa kerja & 40 & 71 \\
Lama & & \\
Baru \\
Tingkat kebisingan & 30 & 54 \\
Tinggi & 26 & 46 \\
Sedang & & \\
Gangguan pendengaran & 34 & 61 \\
Ya & 22 & 39 \\
Tidak & 29 & 52 \\
\hline
\end{tabular}

\section{Analisis Bivariat}

Tabel 2 menunjukkan ada hubungan penggunaan APD dengan gangguan pendengaran $(\mathrm{p}$ value $0,00<0,05)$ dan nilai $O R$ 21,00 $(4,924-89,561)$ artinya tenaga kerja yang tidak menggunakan APD berisiko 21 kali mengalami gangguan pendengaran dibanding dengan tenaga kerja yang menggunakan APD.
Hasil analisis menunjukkan ada hubungan pengetahuan dengan gangguan pendengaran $(\mathrm{p}$ value $0,02<0,05$ ). Nilai $O R$ diperoleh 4,71 $(1,400-15,870)$ artinya tenaga kerja yang pengetahuannya kurang berisiko 5 kali mengalami gangguan pendengaran dibanding tenaga kerja yang pengetahuannya cukup.

Tabel 2 menunjukkan bahwa tidak ada hubungan umur dengan gangguan pendengaran dengan nilai $p$ value $0.099>0,05$. Ada hubungan masa kerja dengan gangguan pendengaran dengan nilai $\mathrm{p}$ value $0,00<0,05$ dan nilai OR 60,00 (10,607-339,402) artinya tenaga kerja yang masa kerjanya lama berisiko 60 kali mengalami gangguan pendengaran dibandingkan dengan tenaga kerja baru.

Tabel 2. Hubungan Penggunaan APD, Pengetahuan, Umur, Masa Kerja, Tingkat Kebisingan dengan Gangguan Pendengaran

\begin{tabular}{|c|c|c|c|c|c|c|c|c|}
\hline \multirow{3}{*}{ Variabel } & \multicolumn{4}{|c|}{$\begin{array}{c}\text { Gangguan } \\
\text { pendengaran }\end{array}$} & \multirow{2}{*}{\multicolumn{2}{|c|}{ Total }} & \multirow[t]{3}{*}{$\mathbf{P}$} & \multirow[t]{3}{*}{$\begin{array}{c}\text { OR } \\
(95 \% \text { IK })\end{array}$} \\
\hline & \multicolumn{2}{|c|}{ Ya } & \multicolumn{2}{|c|}{ Tidak } & & & & \\
\hline & f & $\%$ & f & $\%$ & f & $\%$ & & \\
\hline \multicolumn{9}{|c|}{ Penggunaan APD } \\
\hline Kurang & 24 & 75 & 8 & 25 & 32 & 100 & 0,000 & $\begin{array}{r}21,00 \\
(4,924-\end{array}$ \\
\hline Baik & 3 & 12,5 & 21 & 87,5 & 24 & 100 & & $89,561)$ \\
\hline \multicolumn{9}{|c|}{ Pengetahuan } \\
\hline Kurang & 22 & 61 & 14 & 38,9 & 36 & 100 & 0,021 & $\begin{array}{r}4,71 \\
(1,400-\end{array}$ \\
\hline Cukup & 5 & 25 & 15 & 75 & 20 & 100 & & $15,870)$ \\
\hline \multicolumn{9}{|l|}{ Umur } \\
\hline Tua & 11 & 69 & 5 & 31 & 16 & 100 & 0,099 & 3,30 \\
\hline Muda & 16 & 40 & 24 & 60 & 40 & 100 & & $\begin{array}{l}(0,963- \\
11,312)\end{array}$ \\
\hline \multicolumn{9}{|c|}{ Masa Kerja } \\
\hline Lama & 25 & 83 & 5 & 17 & 30 & 100 & 0,000 & 60,00 \\
\hline Baru & 2 & 8 & 24 & 92 & 26 & 100 & & $\begin{array}{l}(10,607- \\
339,402)\end{array}$ \\
\hline \multicolumn{9}{|c|}{ Tingkat Kebisingan } \\
\hline Tinggi & 22 & 65 & 12 & 35 & 34 & 100 & 0,033 & $\begin{array}{r}3,93 \\
(1,256-\end{array}$ \\
\hline Rendah & 15 & 68 & 7 & 32 & 22 & 100 & & $12,284)$ \\
\hline
\end{tabular}

Berdasarkan tabel 2 disimpulkan bahwa ada hubungan tingkat kebisingan dengan gangguan pendengaran dengan nilai $\mathrm{p}$ value $0,03<0,05$ dan nilai OR 3,93 $(1,256-12,284)$ artinya tenaga kerja yang bekerja di tempat yang tingkat kebisingannya tinggi berisiko 4 
tempat yang tingkat kebisingannya rendah. Analisis Multivariat

Hasil Uji Statistik Regresi Logistik diperoleh nilai $p$-value terbesar adalah pengetahuan 0,944 sehingga variabel pengetahuan dikeluarkan dari model. Setelah pengetahuan dikeluarkan dari model, maka dapat dilihat bahwa variabel umur yang mempunyai nilai p-value sebesar 0,370 dan adanya perubahan nilai OR untuk variabel penggunaan APD, Umur, Masa kerja dan kebisingan yang dapat dilihat pada tabel 3 . Hasil pada tabel 3 menunjukkan bahwa hasil perbandingan OR terlihat tidak ada yang $>10$ $\%$ dengan demikian variabel pengetahuan tetap dikeluarkan dari model. Selanjutnya variabel yang p-valuenya terbesar pada tabel 3 adalah variabel umur, sehingga umur di keluarkan dari model.

Tabel 3. Perubahan Nilai OR setelah variabel pengetahuan

\begin{tabular}{lccc}
\multicolumn{3}{c}{ dikeluarkan dari model sebelumnya } \\
\cline { 2 - 3 } Variabel & $\begin{array}{c}\text { OR } \\
\text { Pengetah } \\
\text { uan ada }\end{array}$ & $\begin{array}{c}\text { OR } \\
\text { Pengetah } \\
\text { uan } \\
\text { Tidak } \\
\text { ada }\end{array}$ & $\begin{array}{c}\text { Perubaha } \\
\text { n OR }\end{array}$ \\
\hline Penggunaan APD & 4,855 & 5,049 & $4,00 \%$ \\
Umur & 2,434 & 2,426 & $0,33 \%$ \\
Masa Kerja & 23,676 & 23,889 & $0,90 \%$ \\
Kebisingan & 5,070 & 5,015 & $1,08 \%$ \\
Pengetahuan & 1,089 & & \\
\hline
\end{tabular}

Setelah umur dikeluarkan dari model didapatkan nilai $\mathrm{p}$-value terbesar penggunaan APD 0,175,sehingga pada model berikut penggunaan APD dikeluarkan dari model, maka dapat dilihat adanya perubahan nilai OR untuk variabel penggunaan APD, Umur, Masa kerja dan kebisingan yang dapat dilihat pada tabel 4 berikut.

Tabel 4 menunjukkan bahwa setelah variabel umur dikeluarkan dari model sebelumnya, perubahan OR semuanya $>10 \%$ dan nilai $p$-value tertinggi adalah nilai penggunaan APD,maka variabel penggunaan APD dikeluarkan dan variabel umur dimasukkan kembali. Setelah penggunaan APD dikeluarkan dari model dan di dapatkan nilai pvalue terbesar adalah variabel umur 0,46 , maka d1lıhat adanya perubahan nila1 UK untuk variabel Umur, Masa kerja dan kebisingan yang dapat dilihat pada tabel 5.

Tabel 4. Perubahan Nilai OR setelah variabel umur dikeluarkan dari model sebelumnya

\begin{tabular}{lcccc}
\hline \multicolumn{1}{c}{ Variabel } & $\begin{array}{c}\text { OR } \\
\text { Umur } \\
\text { Ada }\end{array}$ & $\begin{array}{c}\text { OR } \\
\text { Umur } \\
\text { Tidak } \\
\text { ada }\end{array}$ & $\begin{array}{c}\text { Peruba } \\
\text { han OR }\end{array}$ & $\begin{array}{c}\text { p- } \\
\text { value }\end{array}$ \\
\hline $\begin{array}{lcccc}\text { Penggunaan } \\
\text { APD }\end{array}$ & 4,855 & 4,215 & $13,18 \%$ & 0,175 \\
Umur & 2,434 & - & - & - \\
Masa Kerja & 23,676 & 28,572 & $20,68 \%$ & 0,001 \\
Kebisingan & 5,070 & 4,461 & $12,01 \%$ & 0,106 \\
Pengetahuan & 1,089 & - & - & \\
\hline
\end{tabular}

Tabel 5. Perubahan Nilai OR setelah variabel umur dikeluarkan dari model sebelumnya

\begin{tabular}{lccc}
\hline Variabel & $\begin{array}{c}\text { OR } \\
\text { Pengetahua } \\
\text { n ada }\end{array}$ & $\begin{array}{c}\text { OR } \\
\text { Pengetahua } \\
\text { n Tidak ada }\end{array}$ & $\begin{array}{c}\text { Perubah- } \\
\text { an OR }\end{array}$ \\
\hline Penggunaan & 4,855 & - & - \\
APD & 2,434 & 1,843 & 24,28 \\
Umur & 23,676 & 56,591 & 58,16 \\
Masa Kerja & 5,070 & 4,244 & 16,29 \\
Kebisingan & 1,089 & & \\
Pengetahuan & & & \\
\hline
\end{tabular}

Hasil analisis pada Tabel 6 setelah variabel penggunaan APD dikeluarkan dari model sebelumnya, perubahan OR semuanya $>10 \%$. Untuk melihat hasil analisis model terakhir dapat dilihat pada table 6 .

Tabel 6. Hasil Uji Regresi Logistik Model Terakhir

\begin{tabular}{ccc}
\hline Variabel & $\mathbf{p}$ & $\mathbf{E x p}(\mathbf{B})$ \\
\hline Masa Kerja & 0,003 & $23,889(3,041-187,681)$ \\
Kebisingan & 0,090 & $5,015(0,775-34,444)$ \\
Umur & 0,370 & $2,426(0,350-16,804)$ \\
Penggunaan APD & 0,134 & $5,049(0,607-42,011)$ \\
\hline
\end{tabular}

Berdasarkan tabel 6 terlihat bahwa variabel masa kerja yang berhubungan bermakna (variabel yang paling dominan) dengan gangguan pendengaran dengan nilai OR 23,889 , artinya tenaga kerja yang masa kerjanya lebih lama akan berpeluang 24 kali mengalami gangguan pendengaran.

\section{PEMBAHASAN}


Hasil analisis univariat lebih dari setengah tenaga kerja kurang dalam penggunaan APD hal ini didukung dengan iawaban respon

Sri, dkk Faktor-Faktor Yang Berhubungan Dengan Gangguan...55

mekanik dan lainnya. Secara teknis penentuan jumlah APD adalah jumlah yang diperlukan tergantung iumlah pekeria vang terpapar potenAPD

pengawas tetap tidak menggunakan APD dan pihak perusahaan tidak tegas dalam memberlakukan peraturan tentang keharusan menggunakan APD.

Berdasarkan hasil analisis bivariat menunjukkan bahwa penggunaan APD berhubungan dengan gangguan pendengaran. Hasil ini didukung dengan dengan jawaban responden dengan menggunakan APD saat bekerja dapat melindungi diri dari bahaya/kecelakaan, kendatipun perusahaan tidak menyediakan APD, tetapi tenaga kerja tetap bekerja sambil menunggu APD yang dibutuhkan, mengenai perawatan APD setiap tenaga kerja yang ada APD sudah melakukan perawatan sendiri dengan cara mencuci bila sudah kotor terutama ear muff dan Ear Plug bila sudah dipakai disimpan dalam tempat penyimpanan yang kering dan syarat Ear Plug dan ear muff tidak boleh memodifikasi ukuran dan bentuk.

Hasil penelitian didukung dengan pendapat Achmadi(2008) seyogyanya Ear Plug yang kotor selalu dibersihkan dengan air hangat bila perlu dicampur dengan larutan pembunuh kuman atau jamur, untuk ear muff setelah dipakai harus disimpan di dalam tempat penyimpanan yang kering atau tidak lembab dan jangan sekali-kali memodifikasi ukuran dan bentuk Ear Plug/ear muff yang telah disediakan. Berikut aspek psikologis APD menyangkut masalah kenyataan dalam penggunaan APD sangat penting untuk diperhatikan, timbul masalah baru bagi pemakai yang harus ditanggulangi seperti gangguan terhadap kebebasan gerak pada saat menggunakan APD (Tarwaka, 2008).

Syarat APD yang tidak tepat dapat mencelakakan tenaga kerja yang menggunakannya (Mulyanti (2009). APD menurut OSHA yaitu alat yang digunakan untuk melindungi pekerja dari luka atau penyakit yang diakibatkan oleh adanya kontak dengan bahaya/hazards di tempat kerja baik yang bersifat kimia, biologik, radiasi, fisik, elektrik, lindung dari bahaya potensi yang ada, khususnya yang tidak dapat dihilangkan ataupun dikendalikan serta memahami dasar cara kerja setiap jenis APD yang akan digunakan di tempat kerja.

PT Bio Nusantara Teknologi telah menyediakan APD meliputi safety helmet, Ear Plug, ear muff, masker, gloves (sarung tangan), pakaian pelindung dan safety shoes namun pengadaannya bertahap setelah bekerja dua tahun baru APD lengkap. Pengadaan APD oleh PT BNT sudah sesuai dengan jenis APD khususnya yang berhubungan dengan kebisingan yaitu APT (Alat Pelindung Telinga) adalah alat yang digunakan atau dipakai dengan tujuan melindungi, mengurangi paparan kebisingan masuk ke dalam telinga berupa Ear Plug dan ear muff (Tarwaka, 2008).

Hasil penelitian menunjukkan bahwa lebih dari setengah tenaga kerja berpengetahuan dalam kategori kurang karena pada bagian ini banyak tenaga kerja yang tidak menjawab setelah dikonfirmasi mengapa tidak diisi tenaga kerja,mereka mengatakan tidak mengerti. Pengetahuan tenaga kerja berhubungan dengan gangguan pendengaran dapat disebabkan adanya perbedaan pengetahuan cukup dan kurang tidak terlalu berarti, tenaga kerja yang masuk dalam kategori kurang pengetahuan memang mereka tidak menjawab pertanyaan pada kuesioner begitu dikonfirmasi menjawab kurang paham. Bila jawaban responden dikaitkan dengan pendidikan tenaga kerja sebagian besar mereka pendidikannya SMP dan untuk penggunaan APD sebagian besar tidak menggunakan APD.

Hasil ini berbeda dengan pendapat Notoatmodjo (2011) yang menyatakan pengetahuan merupakan domain yang sangat penting dalam membentuk tindakan seseorang. Upaya PT BNT untuk meningkatkan pengetahuan dan keterampilan tenaga kerja dalam penggunaan APD sudah dilakukan namun masih terbatas dari 56 responden yaitu hanya 18 orang (32\%) 
Hasil menunjukkan bahwa lebih dari setengah tenaga kerja sudah lama masa kerjanya. Hal ini sesuai dengan umur tenaga kerja sebagian besar muda. Masa kerja berhubungan dengan gangguan pendengaran karena sebagian besar tenaga kerja bekerja dalam kategoro baru. Hasil ini didukung dengan pengertian masa kerja menurut Siagian (2008) yaitu adalah berapa lama seseorang bekerja pada masing-masing pekerjaan atau jabatan. Pendapat itu berbeda dengan hasil penelitian. Menurut Siagian (2008) pengertian masa kerja yang lama akan cenderung membuat seorang pekerja lebih merasa betah dalam hal ini karena telah beradaptasi dengan lingkungan sehingga pekerja akan merasa nyaman dengan pekerjaannya. Hal lain didukung dengan umur tenaga kerja sebagian besar dalam kategori muda.

Tingkat kebisingan berhubungan dengan gangguan pendengaran karena tenaga kerja yang menjadi responden merupakan bagian dari proses/produksi dimana tenaga kerja setiap hari terpapar oleh kebisingan terutama tenaga kerja yang berada di pusat dan sekitar titik lima pada pengukuran tingkat kebisingan tertinggi nilainya $125 \mathrm{~dB}>$ dari NAB $85 \mathrm{~dB}$; tingkat kebisingan tertinggi kedua pada lokasi titik empat bagian selatan yaitu 90dB > NAB $85 \mathrm{~dB}$, sedangkan tingkat kebisingan ketiga pada lokasi bagian timur yaitu $86 \mathrm{~dB}>\mathrm{NAB} 85 \mathrm{~dB}$, titik tingkat kebisingan keempat pada lokasi bagian barat yaitu $84 \mathrm{~dB}<\mathrm{NAB} 85 \mathrm{~dB}$ dan tingkat kebisingan yang yang paling rendah pada lokasi bagian utara yaitu $82 \mathrm{~dB}<\mathrm{NAB} 85 \mathrm{~dB}$. Tingginya tingkat kebisingan pada tiga titik pengukuran sesuai dengan hasil jawaban responden melalui kuesioner didukung dengan pengertian kebisingan menurut kementrian lingkungan hidup No Kep 48/MENLH/11/1996 yang menyatakan kebisingan adalah bunyi yang tidak diinginkan dari usaha atau kegiatan dalam tingkat dan waktu tertentu yang dapat menimbulkan gangguan kesehatan manusia dan kenyamanan lingkungan.

Hasil penelitian menunjukkan bahwa sebagian besar umur tenaga kerja dalam kategori muda karena umur tenaga kerja yang paling gangguan pendengaran, karena sebagian besar umur tenaga kerja dalam kategori muda.

Tenaga kerja yang berumur muda masa kerjanya belum lama,namun pada hasil penelitian ini pada tenaga kerja yang muda masa kerja mereka sudah lama karena dari umur muda dan tamat SLTA atau sederajat sudah bekerja di PT BNT dan berdasarkan hasil jawaban semua kuesioner dijawab oleh tenaga kerja yang umur muda dan setelah dikonfirmasi alasannya dengan mengisi semua kuesioner ternyata alasanya karena tenaga kerja sudah meninggalkan waktu kerjanya sementara tenaga kerja pada setiap bagian ada dua sampai tiga orang pada setiap jam operasional mesin yang terus berjalan untuk memproduksi, sehingga waktu yang ada sangat berharga maka sudah seharusnya kami juga bersungguh-sungguh mau diperiksa ke dua telinganya dan mengisi semua kuesioner.

Hasil analisis multivariat berdasarkan langkah-langkah didapatkan variabel yang paling dominan mempengaruhi terjadinya gangguan pendengaran pada tenaga kerja adalah masa kerja dengan nilai $\operatorname{Exp(B)} 23,889$. Hasil ini sesuai dengan hasil univariat dimana lebih dari setengah masa kerja dari tenaga kerja dalam kategori lama, kondisi berikutnya tenaga kerja yang sudah lama masa kerjanya merupakan tenaga kerja yang berada di lokasi dengan tingkat kebisingan yang tinggi dan hasil pemeriksaan audiometric berkisar $30 \mathrm{~Hz}-$ $65 \mathrm{~Hz}$ baik telinga kanan maupun telinga kiri yang memang lebih dari setengah tenaga kerja mengalami gangguan pendengaran (tuli ringan,tuli sedang sampai tuli berat) hal ini sesuai dengan pendapat yang menyatakan bahwa bising dengan intensitas yang tinggi dan dalam waktu yang lama,sehingga akan mengakibatkan robeknya organ corti hingga mengakibatkan destruksi total organ corti, intensitas bunyi yang sangat tinggi dan dalam waktu yang cukup lama mengakibatkan perubahan metabolisme dan vaskuler yang dapat menyebabkan kerusakan degenerative pada struktur sel-sel rambut organ corti,yang mana organ corti rusak mengakibatkan kehilangan pendengaran yang permanen. 
Beberapa kondisi di atas yang memperkuat masa kerja merupakan variabel yang paling dominan. Menurut Siagian (2008) masa kerja adalah berapa lama seseorang bekerja pada masing-masing pekeriaan atau jabatan. Selain itu $b$

Sri, dkk Faktor-Faktor Yang Berhubungan Dengan Gangguan...57

kerja

bangan karier dan kompensasi hasil kerja. Pendapat lain yaitu lama pemaparan kebisingan dapat diartikan sebagai lama waktu bekerja dalam melakukan pekerjaan atau masa kerja pekerja pada ruangan yang sama (Sari, 2012).

\section{KESIMPULAN}

Disimpulkan bahwa gangguan pendengaran yang dialami tenaga kerja PT BNT meliputi tuli ringan,tuli sedang dan tuli berat, lebih dari setengah tenaga kerja kurang dalam penggunaan APD, lebih dari setengah tenaga kerja pengetahuannya kurang, sebagian besar tenaga kerja berumur muda, lebih dari setengah masa kerja tenaga kerja lama dan lama dengan

\section{DAFTAR RUJUKAN}

Achmadi. 2008. Bagaimana Merawat Earplug/Earmuff?, Buletin K4, vol1, hal 6, 28 Maret 2008

Anonim. 2003. Modul Pelatihan Bagi Fasilitator Kesehatan Kerja. Jakarta

Chandra. 2007. Pengantar Kesehatan Lingkungan, EGC: Jakarta

Ganong, William F. 1999. Fisiologi Kedokteran (Review Of Medical Physiology) Terjemahan M Djauhari Widjayakusumah. Edisi 17. Jakarta: EGC.

Guyton, AC. 2001. Buku Tesk Fisiologi Kedokteran Alih Bahasa Adji Dharma dan Lukmanto. Jakarta: EGC.

Habsari, N.D, 2003. Penggunaan Alat Pelindung Diri Bagi Tenaga Kerja, Bunga Rampai Hyperkes dan Keselamatan Kerja, Semarang, UNDIP.

Harrington, JM, and F.S. Gill, 2003. Buku Saku Kesehatan Kerja. Jakarta: EGC.

Joko S. 2002. Deteksi Dini Penyakit Akibat Kerja (Early Detection Of Occupational Desease) WHO. Jakarta: EGC.

Mulyanti. 2009. Faktor Predisposing, Enabling Dan Reinforcing Terhadap Penggunaan Alat Pelindung Diri Dalam Asuhan Persalinan Normal Di Rumah Sakit Meuraxa Banda Aceh.Tesis Pascasarjana USU,Medan.

Notoatmodjo. 2011. Ilmu Kesehatan Masyarakat Ilmu \& Seni. Jakarta: PT Rineka Cipta. tingkat kebisingan yang tinggi $125 \mathrm{~dB}$. Terdapat hubungan yang signifikan antara penggunaan APD, pengetahuan, masa kerja dan tingkat kebisingan dengan gangguan pendengaran tenaga keria PT BNT. Tidak ada

paling dominan mempengaruhi terjadinya gangguan pendengaran adalah masa kerja dengan nilai $\operatorname{Exp}(B)=23,889$.

Diharapkan pada pihak pabrik untuk menyiapkan APD secara lengkap terutama Alat Pelindung Telinga (APT), melakukan pemeriksaan kesehatan tenaga kerja pada bagian proses secara periodik dan teratur untuk memantau kondisi kesehatan fisik terutama sistem pendengaran, dan memberikan reward bagi tenaga kerja yang menggunakan APD secara kontinyu dan punishment bagi tenaga kerja yang sering kali tidak menggunakan APD.

Pearce, Evelyn. 1999. Anatomi dan Fisiologi Untuk Paramedis, Alih Bahasa Sri Yuliani Handoyo. Jakarta: Gramedia.

Pratiknya WA. 2003. Dasar-dasar Metodologi Penelitian Kedokteran dan Kesehatan cetakan ke V. Jakarta: PT Raja Grafindo Persada.

PT Bio Nusantara Teknologi. 2014. Profil PT Bio Nusantara Teknologi. Bengkulu Tengah

Siagian. 2008. Organisasi. Kepemimpinan dan Perilaku Administrasi. Jakarta: Gunung Agung.

Sari. 2012. Pemetaan Tingkat Kebisingan Dan Hubungan Lama Pemaparan Terhadap Gangguan Pendengaran Pada PT. PLN sector Mahakam Samarinda, Jurnal Penelitian Fisika Mulawarman.Vol 8 No 1. Mei 2012.

Sugiyono, 1999, Statitika Untuk Penelitian, Jakarta: CV Alfabeta.

Sumamur , P.K., 1998, Hygiene Perusahaan Dan Kesehatan Kerja, Jakarta: CV Haji Mas Agung.

Tarwaka. 2008. Kesehatan dan Keselamatan Kerja,Manajemen dan implementasi K3 di Tempat Kerja. Surakarta: Harapan press.

WHO. 1986. Early Detection Of Occupational Desease. 